www.jmscr.igmpublication.org Impact Factor 5.244

Index Copernicus Value: 5.88

ISSN (e)-2347-176x ISSN (p) 2455-0450

crossref DOI: _http://dx.doi.org/10.18535/jmscr/v4i6.23

Journal Of Medical Science And Clinical Research

IGM Publication

An official Publication of IGM Publication

\title{
Clinico Pathological Evaluation of Benign and Malignant Soft Tissue Tumors-2 Years Retrospective Study
}

(Original Article)

Authors

Dr Byna Syam Sundar Rao ${ }^{1}$, Dr Bhavana Grandhi ${ }^{2}$, Dr Vissa Shanthi ${ }^{3}$, Dr Vydehi Bheemaraju ${ }^{4}$, Dr Nandam Mohan Rao ${ }^{5}$, Dr Ankita Goel ${ }^{6}$

${ }^{1}$ Associate Professor, Department of Pathology, Narayana Medical College, Nellore (A.P), India Email: syam.byna@gmail.com Cell No: 09493517944

${ }^{2}$ Assistant Professor, Department of Pathology, Narayana Medical College, Nellore (A.P), India

Email: drbhavanagrandhi@gmail.com Cell No: 9642111209

${ }^{3}$ Professor \& HOD, Department of Pathology, Narayana Medical College, Nellore (A.P), India

Email: santhijp@gmail.com Cell No: 9849052179,

${ }^{4}$ Professor, Department of Pathology, Narayana Medical College, Nellore (A.P), India

Email: vydehiramana@gmail.com, Cell No: 9989926096,

${ }^{5}$ Associate Professor, Department of pathology, Narayana Medical College, Nellore (A.P), India

Email: nmr2020KMC@gmail.com Cell No: 9849229201

${ }^{6}$ Assistant Professor, Department of pathology, Narayana Medical College, Nellore (A.P), India

Email:ankig88@yahoo.com Cell No: 9988218311,

Corresponding Author

Dr Byna Syam Sundar Rao M.D

Associate Professor, Narayana medical college

Chintareddy Palem, Nellore - 524002. Department of Pathology

Email: syam.byna@gmail.com, Cell No: 09493517944

\begin{abstract}
Background: Soft tissue tumors are a diverse and heterogeneous group of tumors. The incidence of benign soft tissue tumors are high relative to malignant tumors. The natural course of soft tissue tumors is un predictable and very aggressive if not diagnosed early. Histopathology is considered gold standard in diagnosing soft tissue tumors

Objective: To study the benign and malignant soft tissue tumors with respect to incidence of age, sex and site distribution and study of pathological features of soft tissue tumours.

Materials and methods: Retrospective study was undertaken for a period of 2 years from Dec 2013 to Dec2015 in department of pathology, narayana medical college \& hospital, Nellore, Andhra Pradesh, India.

Results: 90 cases of soft tissue tumors recorded in the department of pathology in 2 years. Of all soft tissue tumors benign soft tumors formed 82 cases (89.1\%) while malignant soft tissue tumours constituted 8cases (10.9\%). The soft tissue tumors in general had slightly male predominance with 2.1:1 is male to female ratio. Commonest benign soft tissue tumor was lipoma and malignant soft tissue tumor was fibrosarcoma in our study. The common site of occurred ce of benign soft tissue tumors was Head \& neck while for malignant soft
\end{abstract}


tissue tumors was extremities. Benign soft tissue tumors were commonly affected in $2^{\text {nd }}$ decade while for malignant tumors were commonly affected in 5th decade.

Conclusion: The histopathological evalution is still the gold standard for the proper diagnosis of soft tissue tumors.

Key words: Soft tissue tumors, benign, malignant, incidence.

\section{Introduction}

Soft tissue tumors are a heterogenous group of tumors and defined as mesenchymal proliferations that occur in non epithelial tissue of the body. Extraskeletal excluding the viscera coverings of brain and lymphoreticular system. Soft tissue tumours are usually divided into benign, intermediate and malignant forms. They can occur at any age group but histological distribution of soft tissue tumors are for definite age and anatomical site ${ }^{(1,2)}$. They usually present as a painless mass.

Benign tumors which closely resemble to normal tissue, have limited capacity for autonomous growth, soft tissue tumors arise nearly everywhere in the body. They can occur at almost any site, both within and between muscles, ligaments, nerves and blood vessels. These tumors vary widely in appearance and behavior. Malignant soft tissue tumors or soft tissue sarcomas are more common than bone sarcomas. They usually occur in adults and present as a large painful or pain less soft tissue mass. Different techniques like excisional, incisional and core biopsy used for diagnosing soft tissue masses. For diagnosis of an extremity soft tissue mass open biopsy is the gold standard investigation (3). FNAC also has an important role in diagnosis of soft tissue lesions, especially CT guided FNAC helpful in diagnosis of intraabdominal and retroperitoneal lesions. Different special techniques like special stains, immunohistochemistry, electron microscopy and cytogenetic, molecular methods are applied to increase diagnostic accuracy of soft tissue tumors. Accurate diagnosis of soft tissue tumors by clinical history like age, duration, location, size, and pathological examination are helpful to make differential diagnosis of the tumor.

\section{Materials and methods}

The present study comprises of 2years retrospective study done from 2013 December to 2015 December conducted in department of pathology, Narayana medical college, Nellore, Andhra Pradesh.. A total number of 90 soft tissue tumors were received during this period. Detailed clinical data including age and sex, Incidence, site of lesion, clinical features, gross and microscopic appearance were taken from histopathology records section. The blocks were cut and stained by routine H\&E stain. Special stains vangeison, PAS, masson's trichome were carried out wherever necessary. Immunohistochemistry was done to confirm the diagnosis.

Inclusion Criteria:- Both benign and malignant tumors of various soft tissue were included.

Exclusion Criteria:- The following were excluded from the study.

1. Tumor like lesions

2. Uterine and gastrointestinal soft tissue tumors were not included in our study.

\section{Results}

Among 90 cases of soft tissue tumors, 82 cases (89.1\%) were benign and 8 cases $(10.9 \%)$ were malignant with male to female ratio is $2.1: 1$ (Graph-1). Benign to malignant ratio of all soft tissue tumors is $8.2: 1$. In our study there were 61 cases $(67.7 \%)$ male and 29 cases $(32.2 \%)$ females. out of 90 cases of soft tissue tumors with male to female ratio2.1:1. Out of 82 cases of benign soft tissue tumors, 59 (71.9\%) were found in males and $23(23.04 \%)$ were found in females (Graph$3)$. Out of 8 cases of malignant tumors there were $5(62.5 \%)$ males and $3(37.5 \%)$ females (Table$5)$. The incidence of both benign and malignant soft tissue tumors were more common in males than female. The male to female ratio among the 
benign soft tissue tumors was $2.5: 1$ and among the malignant soft tissue tumors was 1.6:1. Benign tumors were more common in age groups in less than 30 years with a peak incidence in $2^{\text {rd }}$ decade incidence (41.46\%) (Table-3), while malignant tumors were more common between 51-60 years $(62.5 \%)$. (Table-6). The most common site of occurrence for benign tumors was head and neck 34 cases $(41.46 \%)$ followed by trunk 26 cases $(31.70 \%)$ and extremities 22 cases $(26.82 \%)$ (Table-4) while for malignant soft tissue tumors was extremities 7 cases $(87.5 \%)$ followed by head and neck 1 cases 12.5(\%) (Graph-5). The commonest benign tumor was lipoma 46 cases $(56.09 \%)$ of all benign soft tissue tumors followed by hemangiomas 12 cases (14.63\%), schwanomma10 cases $(12.9 \%)$, neurofibroma 8 cases $(9.7 \%)$, glomus tumor 2 cases $(2.43 \%)$, benign fibrous histocytoma 2 cases $(2.43 \%)$, giant cell tumor of tendon sheath tumor 2 cases $(2.43 \%)$ (Graph-2). Lipomas formed major bulk of benign soft tissue tumors. Head and neck was the common site for lipomas. Haemangiomas were maximum in age group of $0-30$ years with the common site being head and neck. Schwannamas and neurofibromas were more common in age group 21-30 years constituting (6.09\%), respectively and most common site was head and neck. Other benign tumours were benign fibrous histocytoma, glomus tumours, giant cell tumor of tendon sheath . Most common malignant tumours encountered in our study are fibro sarcoma 4 cases (50\%) and liposarcomas 2 cases (25\%). Other malignant tumors of one case each encountered were synovial sarcoma, dermatofibrosarcoma protruberance (12.5\%) (Graph-4).

Graph -1: Incidence of benign and malignant soft tissue tumors

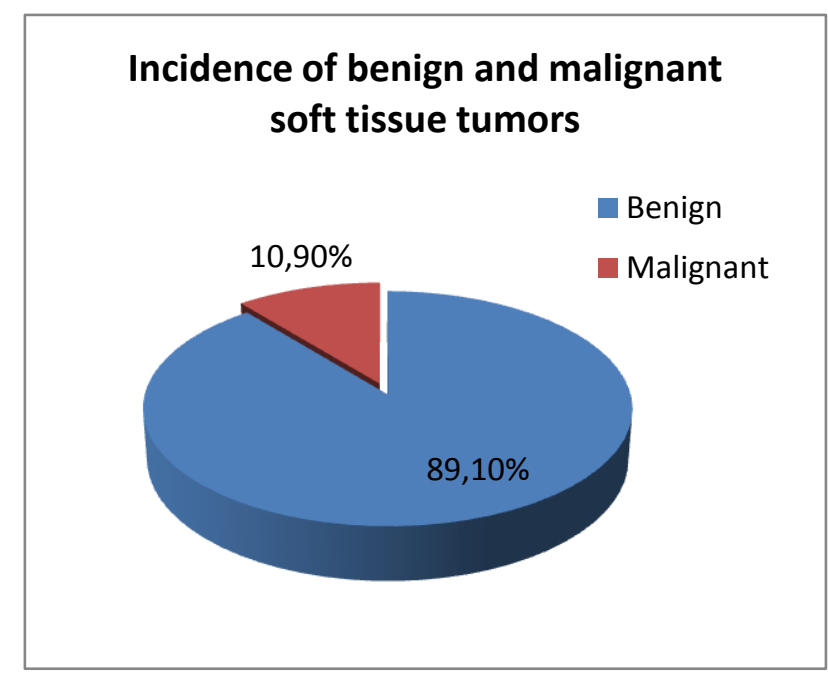

Table-1: Benign and malignant soft tissue tumors ratio in different studies

\begin{tabular}{|l|l|}
\hline studies & Ratio \\
\hline Enzinger & $18.5: 1$ \\
\hline Angerwall et al & $5: 1$ \\
\hline Myhre & $7.2: 1$ \\
\hline Our study & $8.2: 1$ \\
\hline
\end{tabular}

Table-2 : Comparitive study of benign and malignant soft tissue tumors

\begin{tabular}{|l|l|l|l|l|}
\hline Study & M:F & Benign & Malignant & \\
\hline M.J Kransdorf & $1.2: 1$ & 60.2 & 39.8 & - \\
\hline Prameela Jain (2014) & $1.2: 1$ & $90.6 \%$ & $9.4 \%$ & - \\
\hline Dr. M. Janaki etal (2015) & $1: 1$ & $92 \%$ & $4.2 \%$ & $3 \%$ \\
\hline Our study & $2.1: 1$ & $89.1 \%$ & $10.9 \%$ & - \\
\hline
\end{tabular}


Table 3 : Distribution of benign soft tissue tumors according to age group:

\begin{tabular}{|c|c|c|c|c|c|c|c|c|c|}
\hline S.No & Tumors & $\begin{array}{l}\text { Total } \\
\mathrm{N}=82\end{array}$ & $\begin{array}{l}0- \\
10 y r s\end{array}$ & 11-20yrs & $\begin{array}{l}21-30 \\
\text { yrs }\end{array}$ & 31-40 yrs & 41-50 yrs & $\begin{array}{l}51-60 \\
\text { yrs }\end{array}$ & $\begin{array}{l}>60 y \\
\text { rs }\end{array}$ \\
\hline 1 & Lipoma & 46 & 0 & $\begin{array}{l}10 \\
(21.73 \%)\end{array}$ & $\begin{array}{l}15 \\
(32.60 \%)\end{array}$ & $\begin{array}{l}20 \\
(43.47 \%)\end{array}$ & $01(2.17 \%)$ & 0 & 0 \\
\hline 2 & Haemangioma & 12 & 0 & $\begin{array}{l}02 \\
(16.66 \%)\end{array}$ & $\begin{array}{l}07 \\
(58.33 \%)\end{array}$ & $1(8.33 \%)$ & $01(8.33 \%)$ & $\begin{array}{l}01 \\
(8.33 \%)\end{array}$ & 0 \\
\hline 3 & Schwannoma & 10 & 0 & $01(10 \%)$ & $05(50 \%)$ & $02(20 \%)$ & $01(10 \%)$ & $01(10 \%)$ & 0 \\
\hline 4 & Neurofibroma & 8 & 0 & 0 & $\begin{array}{l}05 \\
(62.5 \%)\end{array}$ & $02(25 \%)$ & $01(12.5 \%)$ & 0 & 0 \\
\hline 5 & Benign fibrous histocytoma & 02 & 0 & 0 & 0 & $02(100 \%)$ & 0 & 0 & 0 \\
\hline 6 & Glomus tumors & 02 & 0 & 0 & $\begin{array}{l}02 \\
(100 \%)\end{array}$ & 0 & 0 & 0 & 0 \\
\hline 7 & $\begin{array}{l}\text { Giant cell tumor of tedon } \\
\text { sheath }\end{array}$ & 02 & 0 & 0 & $\begin{array}{l}02 \\
(100 \%)\end{array}$ & 0 & 0 & 0 & 0 \\
\hline & Total & 82 & 0 & 13 & 38 & 25 & 4 & 2 & 0 \\
\hline
\end{tabular}

Graph-2 : Incidence of benign tumors.

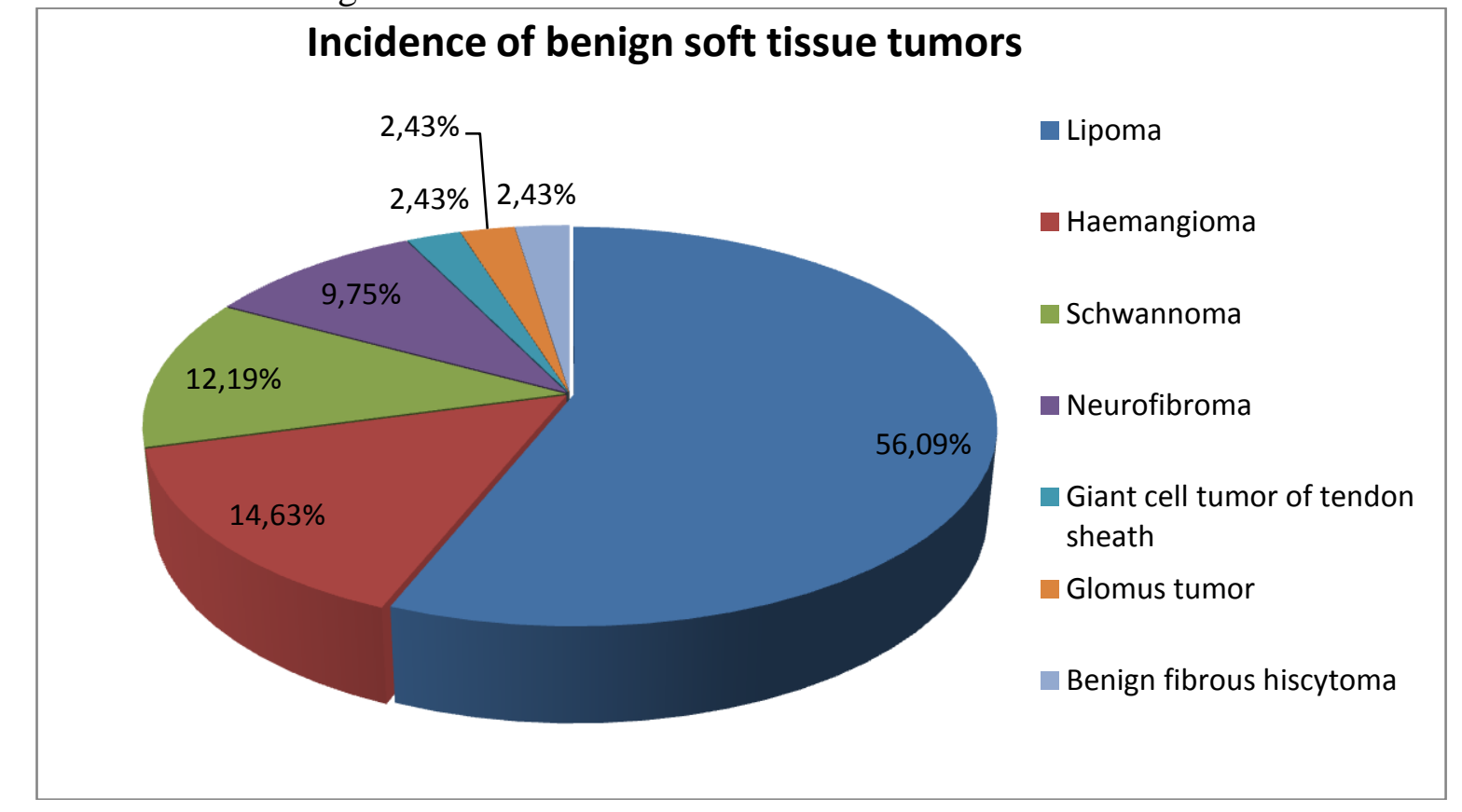


Graph-3 :Distribution of benign soft tissue tumor according to gender

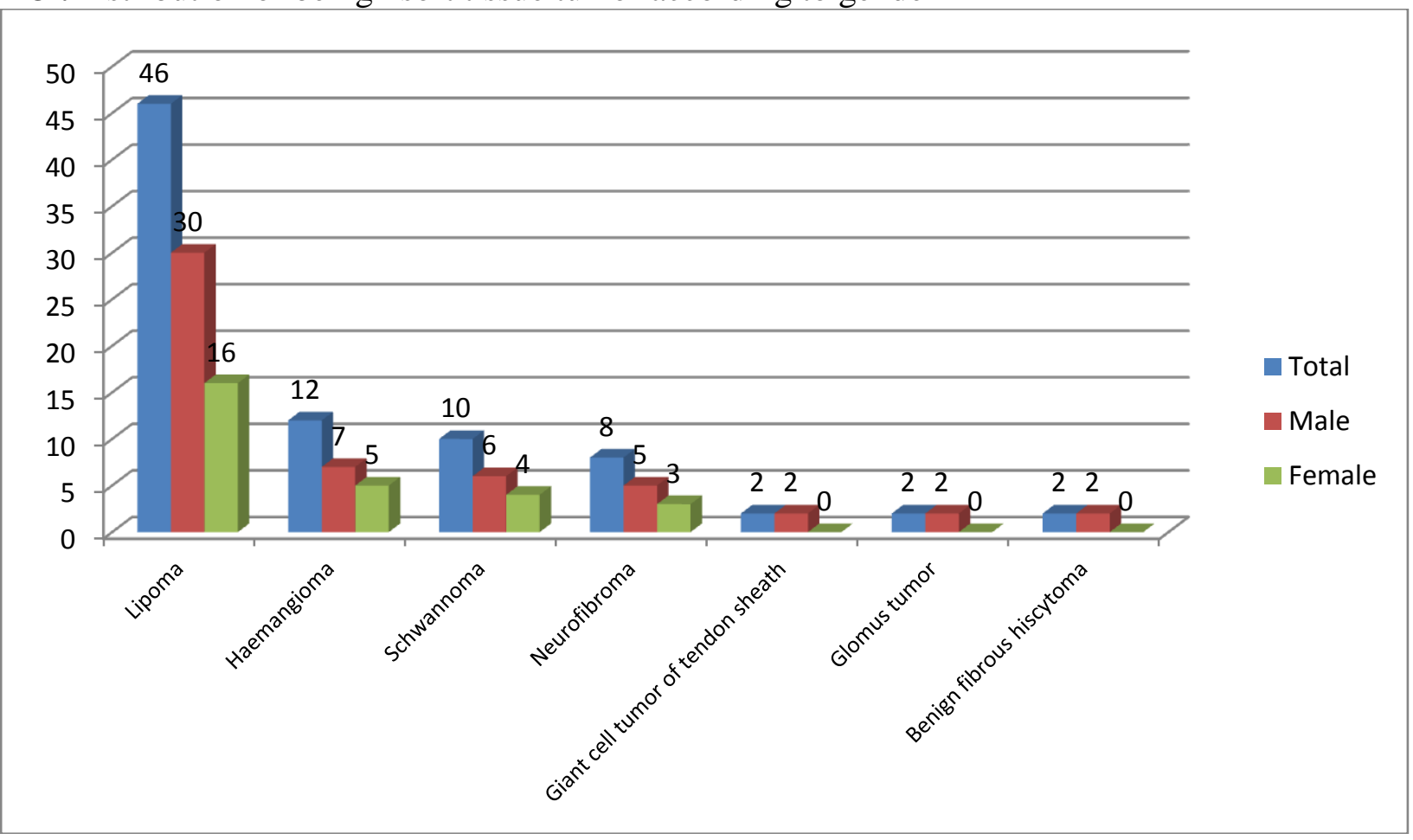

Table - 4: Distribution of benign soft tissue tumors according to site.

\begin{tabular}{|c|c|c|c|c|c|c|}
\hline \multirow{2}{*}{ S.No } & \multirow{2}{*}{ Tumors } & \multirow{2}{*}{$\begin{array}{l}\text { Total } \\
\mathrm{N}=82\end{array}$} & \multirow{2}{*}{$\begin{array}{l}\text { Head \& Neck } \\
n=34(41.46 \%)\end{array}$} & \multicolumn{2}{|c|}{ Extremities $n=22(26.82 \%)$} & \multirow{2}{*}{$\begin{array}{l}\text { Trunk } \\
n=26(31.70 \%)\end{array}$} \\
\hline & & & & Upper $n=14$ & Lower $n=8$ & \\
\hline 1 & Lipoma & 46 & $20(43.47 \%)$ & $6(13.04 \%)$ & $2(9.30 \%)$ & $16(34.7 \%)$ \\
\hline 2 & Haemangioma & 12 & $6(50 \%)$ & $1(8.33 \%)$ & $1(8.33 \%)$ & $4(33.33 \%)$ \\
\hline 3 & Schwannoma & 10 & $3(30 \%)$ & $1(10 \%)$ & $4(40 \%)$ & $1(40 \%)$ \\
\hline 4 & Neurofibroma & 8 & $5(62.5 \%)$ & 0 & $1(12.5 \%)$ & $2(25 \%)$ \\
\hline 5 & $\begin{array}{l}\text { Giant cell tumor of } \\
\text { tendon sheath }\end{array}$ & 2 & - & $02(100 \%)$ & - & - \\
\hline 6 & Glomus tumor & 2 & - & $02(100 \%)$ & - & - \\
\hline 7 & $\begin{array}{ll}\text { Benign } & \text { fibrous } \\
\text { hiscytoma } & \end{array}$ & 2 & - & $02(100 \%)$ & - & - \\
\hline
\end{tabular}


Graph-4 shows incidence of sarcomas

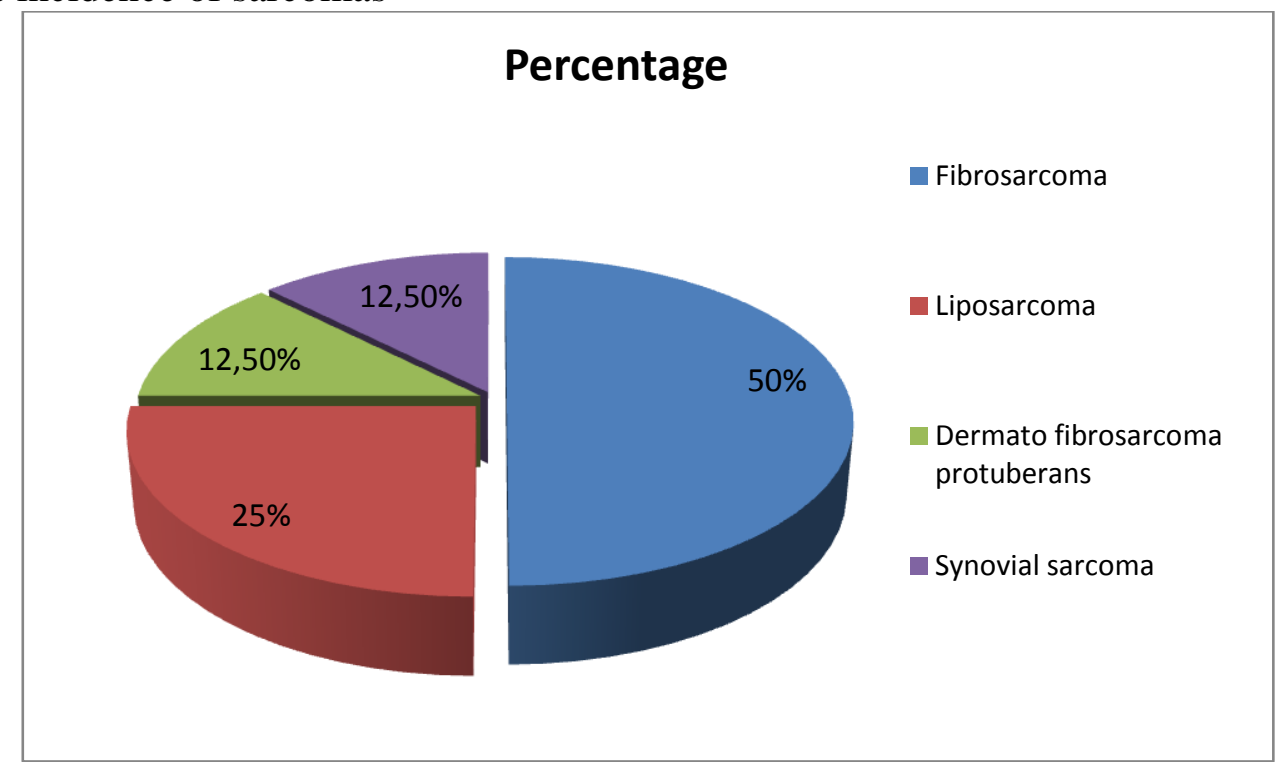

Table-5: Distribution of sarcomas according to gender

\begin{tabular}{|l|l|l|l|}
\hline & Sarcomas & Males & Females \\
\hline 1 & Fibrosarcoma(4 Cases) & $3(75 \%)$ & $1(25 \%)$ \\
\hline 2 & Liposarcoma(2 cases) & $1(50 \%)$ & $1(50 \%)$ \\
\hline 3 & Dermato fibrosarcoma protuberans (1case) & $1(100 \%)$ & 0 \\
\hline 4 & Synovial sarcoma(1case) & $1(100 \%)$ & 0 \\
\hline
\end{tabular}

Table-6: Distribution of sarcomas with respect to age.

\begin{tabular}{|l|l|l|l|l|l|l|l|l|l|l|}
\hline S. No & Sarcomas & Total & $0-10 \mathrm{yr}$ & $11-20 \mathrm{yr}$ & $21-30 \mathrm{yr}$ & $31-40 \mathrm{yr}$ & $41-50 \mathrm{yr}$ & $51-60 \mathrm{yr}$ & $>61 \mathrm{yr}$ \\
\hline 1 & Fibro sarcoma & $4(50 \%)$ & 0 & 0 & 0 & 0 & 0 & $1(12.5 \%)$ & $3(37.5 \%)$ \\
\hline 2 & Lipo sarcoma & $2(25 \%)$ & 0 & 0 & 0 & 0 & 0 & $2(25 \%)$ & 0 \\
\hline 3 & $\begin{array}{l}\text { Dermato } \\
\text { fibrosarcoma } \\
\text { protuberans }\end{array}$ & $1(12.5 \%)$ & 0 & 0 & 0 & 0 & $1(12.5 \%)$ & & 0 \\
\hline 4 & $\begin{array}{l}\text { Synovial } \\
\text { sarcoma }\end{array}$ & $1(12.5 \%)$ & 0 & 0 & 0 & 0 & 0 & $1(12.5 \%)$ & $\mathrm{O}$ \\
\hline 7 & Total & $8(100 \%)$ & 0 & 0 & 0 & 0 & 0 & $5(62.5 \%)$ & $3(37.5 \%)$ \\
\hline
\end{tabular}


Graph-5 shows distribution of sarcomas according to site

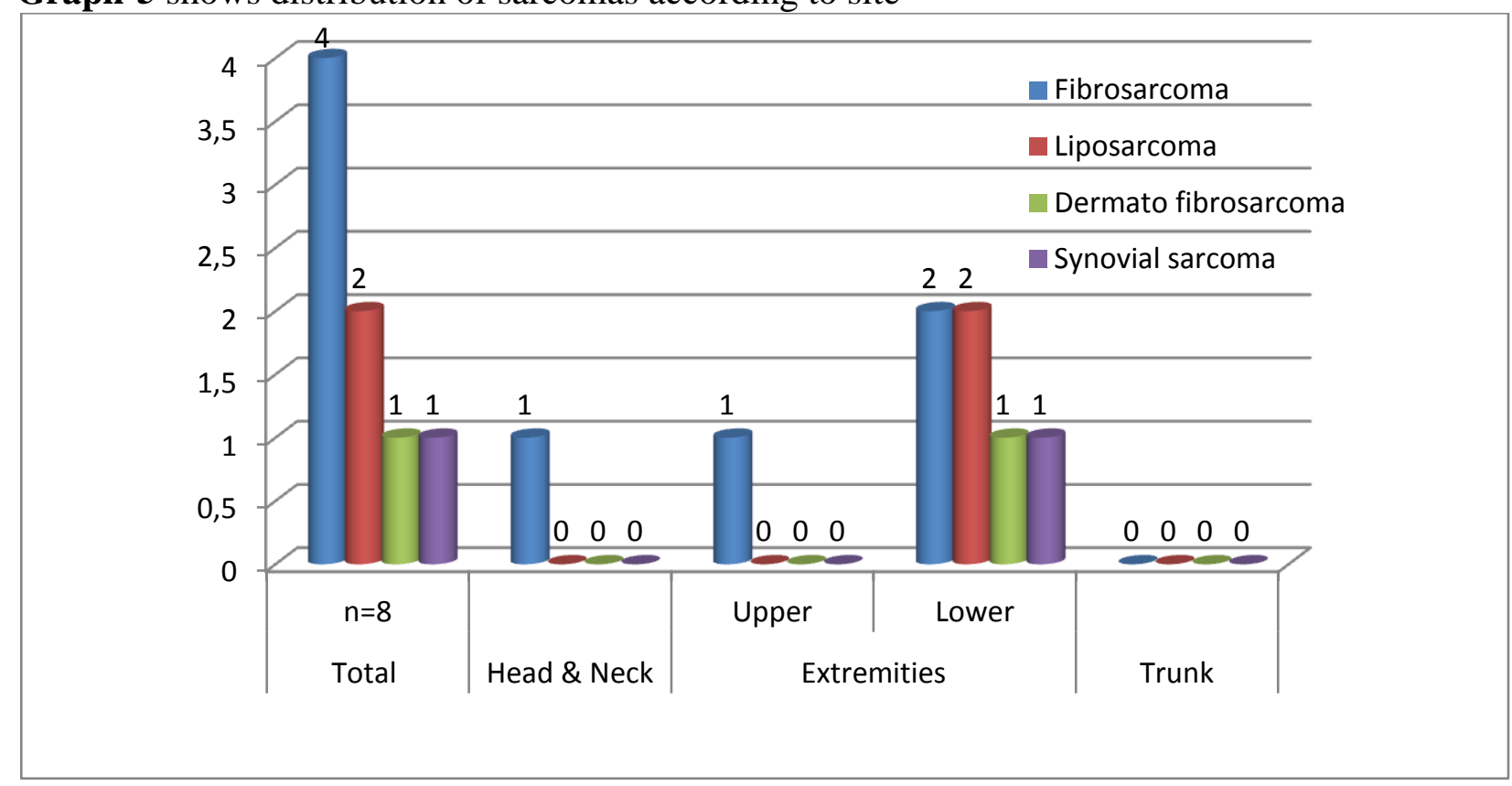

\section{Discussion}

Soft tissue is a non epithelial extra skeletal tissue of the body exclusive of reticuloendothelial system, glia and supporting tissue of the various parenchymal organs. It is represented by the voluntary muscles, adipose tissue and fibrous tissue and vessels serving these tissues. The main purpose of this study was to assess the benign and malignant soft tissue tumors with respect to age \& gender, site distribution and to compare this with other similar studies. Recognized causes include various chemical and physical factors, exposure to ionizing radiation, inherited or acquired immunological defects. Evaluation of the exact cause is difficult because of the long latent period. Benign soft tissue tumors were more common than malignant tumors in our study, similar to the studies by Myhre Jenson et al ${ }^{(5)}$, Angerwall et al (6) Enzinger F.M.S.W(4) (Table-1) . In our study there were 61 cases $(67.7 \%$ ) male and 29 cases (32.2\%) females. out of 90 cases of soft tissue tumors with male to female ratio 2.1:1 which is similar to the study of M.S.Krans dorf ${ }^{(1)}$, Prameela Jain et al ${ }^{(7)}$, M Janaki et al ${ }^{(8)}$ (Table-2). In the present study benign soft tissue tumors were found more commonly in males than females with $\mathrm{M}: \mathrm{F}$ of $2.1: 1$, similar to observations made by Costa $\mathrm{J}$ et al ${ }^{(9)}$.

In our study the commonest benign soft tissue tumor is lipoma (56.09\%) followed by hemangioma (14.63\%). These findings almost similar to study carried out by Bharti G Ramana et al ${ }^{(11)}$. Lipomas formed major bulk of benign soft tissue tumors $(56.09 \%)$. The Common site of lipoma was Head and Neck in our study where as in the study carried out by Ander Rydhlom et al trunk was the common site. Incidence and gender distributions of this lesion were correlated with Ander Rydhlom et al ${ }^{(10)}$. Lipoma was most common in age group 21-50 years with maximum cases in 31-41 years $(43.47 \%)$ and males were commonly affected than females whereas study carried out by Ander Rydholm showed most common age group was 41-50 years. Grossly lipoma is round to oval encapsulated mass and cut surface is lobulated homogenous yellowish and greasy. Microscopically the lesion shows lobules of mature adipocytes which are separated by thin fibrous septa. Fibrous capsule surround the tumor. The hemangiomas 12 cases $(14.63 \%)$ were the next common benign tumors. Hemangioma were maximum in age group of 0-30 years and was found to be more common in males and 
commonest site was head and neck especially in oral cavity. These findings are similar to study carried out by (17.5\%) Bharti G Ramana et al ${ }^{(9)}$. Hemangiomas are common lesion especially in infancy and childhood. Capillary hemangioma type is the most common type. Clinically the lesion appear as small or large, flat, slight elevated, measures few millimeters to few centimeters. Microscopically the lesion is composed of thin walled blood vessels which are lined by single layer of plump endothelial cells. The vessels are separated by loose connective tissue stroma. Cavernous hemangiomas are single or multiple and measures 1 to $2 \mathrm{~cm}$ in diameter. Microscopically the lesion composed of thin walled large dilated cavernous spaces which are lined by flat endothelial cells. The vessels are separated by scanty connective tissue stroma.

In the present study schwanomma constituted 10 cases (12.9\%) of benign soft tissue tumors. Gender and site distribution of this lesion were correlated with Bharati $G$ ramana et al ${ }^{(9)}$. The incidence of the lesion in our study (12.9\%) is slightly higher than in the study carried out by (5\%) Bharati $\mathrm{G}$ ramana et al ${ }^{(9)}$. In the present study most common age incidence of schwanomma 5 cases (50\%) were between 20-30 years whereas study carried out by Bharati G ramana et al showed most common age group was 31-60 years. Grossly schwanomma is encapsulated grey white tumor. Cut section shows grey white solid and focal cystic areas. Microscopically the tumor is composed of Antoni A (cellularity) pattern, Antoni B (loose acellular) pattern. Antoni A Pattern shows spindle cells with palisaded nuclei forming verocay bodies. In the present study neurofibroma constituted 8 cases $(9.75 \%)$ of benign soft tissue tumors in our study which is almost similar to study carried out by (7.5\%) Bharti G Ramana et al ${ }^{(9)}$. Neurofibroma constituted 8 cases $(44.4 \%)$ of benign peripheral nerve sheath tumors(18 cases) in our study and common age group of 21-50 years with male predominance. These findings were almost similar to study carried out by (45.46\%) Sushma K Gabhana et al ${ }^{(12)}$. The common site of neurofibroma was Head and neck in our study but these cases had no specific site preference in literature. Grossly neurofibroma is encapsulated lobular grey white mass. Cut surface shows gelatinous and grey white firm areas. Microscopically the tumor shows interlacing bundles of spindle cells having wavy nuclei.These tumor cells are separated by myxoid areas. Focal nerve fibres are noted.

In the present study glomus tumor constituted about 2 cases $(2.43 \%)$ of benign soft tissue tumors with age range of 20-30 years and both the cases in upper extremity. The site distribution finding of glomus tumor in our study similar to Riveros et al ${ }^{(13)}$. These lesions are characterized by single or multiple, $<1$ or $1 \mathrm{~cm}$ in diameter and flat or elevated painful nodule. Microscopically the tumor shows small blood vessels lined by endothelial cells and surrounded by nests of tumor cells. The tumor cells are round to cuboidal with scanty cytoplasm and tumor cells are separated by fibro connective tissue. In our study giant cell tumor of tendon sheath constituted about 2 cases $(2.43 \%)$ of benign soft tissue tumors with age range of 31 - 40 years with male preponderance and predominant site was hand. Incidence of giant cell tumor of tendon sheath $(2.42 \%)$ in our study was correlated with $(2.5 \%)$ Bharti G Ramana etal (11). Age, gender and site distribution of this lesion were correlated by study carried out by Dar wish FM et al ${ }^{(14)}$. Grossly it present as small well circumscribed lobulated mass. Cut section shows grey white to grey brown areas. Microscopically the lesion shows multinucleated giant cells, small histocytes, fibro connective tissue. Areas of hemorrhages, hyalinization, hemosiderin macrophages are noted. In our study Benign fibrous histocytoma constituted about 2 cases $(2.43 \%)$ of benign soft tissue tumors with age range of 21-30 years with male preponderance and predominant site was upper extremities. Incidence of benign fibrous histocytoma $(2.43 \%)$ in our 
study was correlated with (4.2\%) Bharti G Ramana et al ${ }^{(11)}$. Age, gender and site distribution of this lesion were correlated by study carried out by Caloneje et al ${ }^{(15)}$. Grossly it is well defined lesion with a tan white cut surface. Microscopically it shows bland spindle cells arranged in short fascicles and storiform pattern, scattered chronic inflammatory cells and occasionally giant cells are noted.

In our series male prevalance was predominant than females in malignant soft tissue tumors. Our finding were similar to other studies like wibmerc et al ${ }^{(16)}$, kransdorf MJ ${ }^{(2)}$. In our study soft tissue sarcomas constituted 8 cases $(10.9 \%)$ and commonest site was extremities followed by Head and neck. This findings was correlated with Mardong et al ${ }^{(17)}$. In our study male to female ratio of soft tissue sarcoma was 1.6:1, which is very close to study of Abudu et al ${ }^{(18)}$. In the present study fibrosarcomas constituted an incidence 4 cases $(50 \%)$ of all soft tissue sarcomas and most common age group was $60-70$ years. Fibrosarcoma comprises $12 \%$ according to Pitchard D J et al ${ }^{(19)}$. The incidence finding of this lesion in our study differed with study carried out by Pitchard D et al ${ }^{(19)}$ due to variation of sample size. Commonest site of this lesion was extremities and this finding correlated with Enzinger F.M.S.W ${ }^{(4)}$. Grossly fibrosarcoma is a grey white firm lobulated mass. Cut surface the tumor is soft grey white with foci of necrosis and hemorrhages. Microscopically the tumor is composed of spindle shaped cells arranged in fascicles and hering bone pattern. Tumor cells having nuclear pleomorphisim and moderate mitotic activity. In the present study liposarcoma constituted 2 cases (25\%) of all soft tissue sarcomas with equal sex incidence and common site was extremities. All cases are affected between 50-60 years. These findings were correlated by study carried out by $(10-25 \%)$ Coasta $\mathbf{J}$ et al ${ }^{(9)}$. Grossly the tumor is a nodular mass and circumscribed. Cut surface shows grey white to yellow and gelatinous appearance.
Microscopically tumor shows tumor cells which are round to oval, spindle type with hyperchromatic nucleus and vaculoated cytoplasm.

In the present study derma to fibro sarcoma protruberaus constituted 1 case $(12.5 \%)$ of all the soft tissue sarcomas and most common age group was 40 - 50 years with male predominance and case was noted in extrimities. The incidence finding of this lesion was different with the study carried out by $(1.1 \%)$ Gutierez $\mathrm{G}$ et al ${ }^{(20)}$ due to variation of sample size. Age, gender and site distribution of this lesion were similar to study carried out by Gutierez $\mathrm{g}$ et $\mathrm{al}^{(20)}$. Grossly dermatofibrosarcoma is solitary or multiple nodules having thin and ulcerate skin surface. Microscopically the tumor shows spindle type cells arranged in storiform pattern with nuclear pleomorphism, and moderate mitotic activity. Tumor cells infiltration in to subcutaneous tissue is seen. In present study synovial sarcoma disclosed an incidence (12.5\%) of all soft tissue sarcomas which is almost similar to (6-15\%) Coasta $\mathrm{J}$ et al $1988^{(9)}$. Our study revealed one male case noted in 50-60 years and site was extremities. Site distribution of this lesion was correlated with study carried out by Leslie etal ${ }^{(21)}$ but age and gender findings in our study differ with Leslie et al ${ }^{(21)}$. Grossly synovial sarcoma is of variable size and grey white lobulated encapsulated mass. Cut section shows fish flesh like appearance with foci of cystic spaces and areas of hemorrhages and necrosis. Microscopically the classical form of synovial sarcoma is biphasic pattern consists of epithelial cells and sarcomatous components. The epithelial cells appear in the form of gland like space lined by cuboidal or columnar cells. The sarcomatous component is pleomorphic spindle cells arranged in whorled, fasicles pattern. Areas of hyalinization, calcification noted in the stroma. Important diagnostic features are cell morphology and architectural arrangement; often these features are not sufficient to distinguish one sarcoma from 
another. Precise histological classification provides significantly to establishing the prognosis of sarcoma. Grading of a malignant soft tissue tumors are based on cellular pleomorphisim, number of mitosis per high power field, degree of differentiation and extent of necrosis. Finally the histo pathological evaluation is the gold standard for proper diagnosis of soft tissue tumors. Soft tissue sarcoma is largely based on degree of differentiation, number of mitosis per high power field, cellular pleomorphism and extent of necrosis.

\section{Conclusion}

Soft tissue tumors have been very interesting to pathologist for many years because of different varieties and similarities of histopathological features between tumors with delicate difference detectable on careful microscopic examination. Adequate sampling of the tumors, gross examination, special stains and immune histochemistry are helpful in addition to routine Haematoxylin and eosin stain for definitive diagnosis of soft tissue tumors.

\section{Source of support: Nil \\ Conflicts of interest: Nil}

\section{References}

1. Kransdorf MJ; Malignant soft tissue tumors in a large referral population; distribution of specific diagnosis by age,sex and location, AJR AMJ Roentgenol., 1995;164(1):129-134

2. Kransdorf MJ; Benign soft tissue tumours in a large referral population distribution of specific diagnoses by age, sex, and location. AJR Am J roentgenol MJ; 1995; 164(2) : 395-402

3. Kasraeian S,Allison,DC,Ahlmann ER, Fedenko AN,Menendez LR;A comparision of Fine needle aspiration,core biopsy,and surgical biopsy in the diagnosis of extremity soft tissue mass.clin ortho Relat Res.,2010;468:2992-3002.

4. Enzinger F.M\& Weiss S.W. soft tissue tumours st.louis . The CV mosbyco 1988.

5. Myhre, Jenson o etal. Histopathological staging in soft tissue tumours in relation to in 261 surgically treated patients. Acta pathol, microbial. Immunol seana (A) $91: 145$

6. Angervall L ETAL. The diagnosis and prognosis of soft tissue tumors semin diagn. Pathol 3:240.

7. Pramila Jain, Archana Shrivastava,Reeni Malik. Clinicomorphological Assessment of soft tissue tumors. Sch.J. App.Med.Sci,2014;2(2D):886-890.

8. M.Janaki, K..V ijaya satish Arora, Swarooparani, M.Phani Kumar,Sandhya krupal.Morphological study of soft tissue tumors.IJRHS, april-jun 2015,vol-3, issue2:364-368.

9. costa.J.etal. The grading of soft tissue sar comas . Results of a clinicopathological correlation in a series of 163 cases. Cancer 1984;53;530

10. Rydholm A Berg. No. size, site \& Clinical incidence of lipomas. Factors in differential diagnosis of lipoma and sarcoma. Act Orthop seand 54:929, 1983

11. Bharti G Ramnani,Ashutosh kumar,Shruti Chandak,Amar Ranjan, AND Mehul kumar Patel.clinico pathological profile of Benign soft tissue tumors: A study in a Tertiary care hospital in western India,journal of clinical diagnostic research 2014 oct:8(10):1-7

12. Gabhane sushma K, etal . Morphological spectrum of peripheral nerve sheath tumours : A series of 126 cases. IAPM.2009; 52;(1);29-33

13. Manuel Riveros. The glomus tumors reports of 20 cases.Am.surg.1951;133:394

14. Darwish FM,Haddad WH.Giant cell tumor of tendon sheath:experience with 52 
cases.Singapore MED J.2008;49(11):879-

82.

15. Calonje E,et al.Cellular benign fibrous histocytoma.clinicopathological analysis of 74 cases of a distinctive variant of cutaneous fibrous hiscytoma with frequence recurrence. Am J Surg Pathol. 1994;18(7):668-76.

16. Wibmer C, Leithner .A, zielanke n, sperd $M$, windhager $R$. Increasing incidence rates of soft tissue sarcomas? A population based epidemiological study and literature review. Ann on col . 2010;21(5):1106-11

17. Mandong BM,Kidmas AT,Manasseh AN, Echejoh GO,Tanko Madaki AT; Epidemiology of soft tissue sarcomas in jos,North central ,Nigeria.Niger j Med, 2007;16(3):246-249

18. Abudu EK,AKinde OR,Oyebadejo TO, Efunshile AM,Musa OA,Banjo AA: Histopathological study of soft tissue malignancies in a teaching hospital, sagamu, South-west Nigeria. Nig Q J Hosp Med;2010;20(1):42-45.

19. Pritchard DJ etal.Clinico pathological \& statistical study of 199 tumors of soft tissues. cancer 33:888,1974

20. Gutirez.G tal. Dermatofibrosarcoma protruberans -review of 30 cases Int.j. Dermat US 1984

21. Leslie A et al.Histologic features relating to prognosis in synovial sarcoma.cancer 59:1810-1814,1987. 